\title{
A DANGEROUS METHOD: DYNAMIC CLINICAL PSYCHOLOGY AND THE CHALLENGE OF UNDERSTANDING EMOTIONALITY IN SOCIAL CONTEXTS*
}

\author{
Viviana Langher ${ }^{1}$ \\ Department of Dynamic and Clinical Psychology \\ Sapienza University, Rome, Italy
}

\begin{abstract}
This contribution aims to discuss how and to what extent emotionality affects opinions, beliefs, attitudes, therefore, the social behaviour of entire communities. The construct of the unconscious is presented in a modern perspective, beyond the individual vicissitudes of personal conflicts, unresolved experiences, and psychopathology. Based on Matte Blanco's bi-logic theory of mind (1975), emotions, as a process of attribution of meaning to objects, persons and events, grounded on primary categories (such as, good and evil, big and small, inside and outside), may be shared by groups of individuals as well as entire communities in the form of "local cultures" (Carli \& Paniccia, 2003), regulating their social behaviour towards given social stimuli. Dynamic clinical psychology offers a theoretical framework, instruments and methodologies, such as the Emotional Text Analysis based on the lexical analysis of language, and ability to uncover this portion of shared emotionality in social contexts so that it can be made explicit, elaborated and transformed in unbiased and aware rational thoughts. Two case studies are briefly presented showing how dynamic clinical psychology can offer an "across the board" knowledge that can be fruitfully integrated in different fields, helping other professional profiles in designing and realizing practical solutions to improve communities' quality of life, including their capacity to manage complex sets of information, thus preventing an abundance of stereotypes, simple thoughts, and primary emotions. I will conclude with a call on university teachers on their responsibility in supporting open mindedness in young generations and their ability to explore different contexts.
\end{abstract}

Keywords: Emotional Text Analysis, local culture, case study

\footnotetext{
${ }^{1}$ viviana.langher@uniroma1.it

* Note: Speech given at the International Week "Challenges of Teaching and Research in Humanities and Social Sciences" organized by the Faculty of Philosophy, Ss. Cyril and Methodius University in Skopje, Macedonia
} 


\section{The unconscious in social contexts}

When we refer to the term "unconscious", we usually focus on the secrets that our complex mind can contain and hide. This is some sort of "layman approach", since the term "unconscious" has become of common use. However, in the contemporary field of theoretical, empirical and clinical research in dynamic clinical psychology (see, for example, Grasso \& Salvatore, 1997; Salvatore et al., 2003), some scholars conceptualize the unconscious as a different logic organizing the functioning of mind. Some of them stress more the "implicit" elaboration of information concerning the relationship between individuals and their contexts (context made by persons, objects and events) and they are considered close to the cognitive conceptualization of "unconscious". Other scholars refer more directly to the psychoanalytic tradition and consider the unconscious as a process of emotional attribution of meaning based on affective symbolizations, different from the perceptive, rational, cognitive attribution of meaning based on the operative symbolization (Fornari, 1975; 1976). In this framework, the human mind is conceived as based on a bi-logic (Matte Blanco, 1975): the rational, cognitive, dividing, heterogenic logic on one side, and the emotional, generalizing, symmetric logic on the other side. The first one is based on the Aristotelian principles of identity, non-contradiction and tertium non datur. The second one refers to the principle of symmetry and generalization (Matte Blanco, 1975). While the rational mind gets to know the world thanks to a sophisticated way of recognizing the differences between objects (and persons and events); the emotional mind gets to know the world by putting the objects (and persons and events) in wide emotional classes, full of elements that are different (according to the rational logic) yet treated as they were the same (according to the emotional logic). The emotional classes are primary, simple, extreme: good/evil, big/small, inside/outside, etc.

One promising implication of this approach, and one of the most modern theoretical and empirical developments, is the analysis of interpersonal and social phenomena in terms of unconscious processes. Groups of individuals, belonging to the same context, share a double knowledge of it: the rational and the emotional one. For example, let's consider a university hall: it is well known as a place dedicated to knowledge and learning, there are chairs and tables and boards, experts are supposed to talk and explain, and other people are supposed to listen quietly and ask polite and clever questions. We all may agree on this generic description based on reality testing. Similarly, we feel that this university hall is a good place containing precious things (knowledge, ideas, creativity - 
symbolically life?) inside, and keeping bad things (ignorance, limitations symbolically death?) outside. Emotionally it is a good microcosm, separated and protected by a potentially gross, vulgar or trivial macrocosm outside. We would fight to protect it and would not let someone harm it. However, the same university hall could be emotionally perceived as hell, if a cohort of students would be here to pass the hardest exam of their academic life. Teachers would be perceived as evil, persecutory, disregarding, sadistic commanders playing with their life. I am exaggerating and we can laugh at this picture, but I am sure that each of us has felt as a teacher, at least one moment of true hate by one student during his/her hardest exam - without deserving to be hated in reality.

This interpersonal, social unconscious way of functioning can be detected in any organization. I hereby refer to every stable set of interpersonal relations delimited by structural or functional or even geographical boundaries, where the emotionality is shared by the individuals for the purpose of regulating their set of meanings and, consequently, their behaviour. We use the term "collusion" (Carli \& Paniccia, 2003) for the unconscious emotional agreement on the meaning of interpersonal relationships which allows us to foresee and to expect something from the others in a quite certain way. We use the term "local culture" (Carli \& Paniccia, 2003) for the set of collusions stabilizing the coexistence in a given context. According to this perspective, it is possible to uncover the portion of shared emotionality so that it can be made explicit, elaborated and transformed in unbiased and aware rational thoughts.

For example, let's consider a company owned by a charismatic old man. All the individuals participating in this context emotionally share a set of meanings, for example that the company is like a huge family, where people love and support each other, where the father-like owner is respected even when he is inflexible, because he is supposed to do the right thing. Of course, if you ask these people to talk about their company, they are perfectly capable to understand that they are working in a company and not enjoying the warmth of a family, but you can catch in their words, during their appropriately rational speeches, certain clues about their emotional meaning. For example, they can use expressions like: I feel safe, we're friends, the boss takes care of us, and so on. This local culture can be very effective in maintaining good functioning of the company: pushed by the feeling to be a huge family, every individual of this context can make efforts in order to make the boss glad, or the colleagues satisfied. In this case, the local culture is syntonic with the aims of the company, which are to produce products and to make some profit. Let's say now that the old boss retires and gives the highest position to a young talented manager. This is a rational choice, well 
proven and not easily questionable. However, it can be the beginning of a crisis: people feel betrayed, especially the ones from the old guard, rumours arise that the new boss manipulated the old boss, some however think that the old boss did good, others feel that nothing will remain the same, etc. They can use words like disappointment, loyalty, bonds, gratitude, anger, etc. The same local culture, based on familial feelings, now becomes not compatible with the aims of the company, and the productive process may fall into a stall.

Dynamic clinical psychology may diagnose these local cultures, and psychologists working in accord with this perspective can support groups of individuals to understand and reflect on these emotional sets, as well as to elaborate more advanced and mature thoughts - which in turn make place for a different local culture, more differentiated and syntonic with the new arrangement. In the example with the company, the rearranged local culture may contain the same familial tangle, but more openness to the exploration of the other, which means that the new boss may be perceived as a good and competent boss after all, and that it may be worthy to make efforts for the company even if the new boss is less able to make his employees feel at home.

Language is one of the most sensitive domains expressing the socialized emotions of groups. It is obvious that an individual can express the same concept with a totally different emotional connotation. For example, referring to a person, one can say "she's a good mother" or "she's a good mom" and with this slight lexical difference s/he communicates two different emotional meanings. Furthermore, the listener can feel higher emotional involvement with the second statement than with the first one.

There is a second characteristic of language that can be considered as a way to access the profound emotional meanings encoded in a given context: the association between words. This approach is based on the classic psychoanalytic technique of free associations: the patient is invited by the psychoanalyst to talk freely, without concern about the coherence or appropriateness of what s/ he is saying: s/he is invited to associate adjectives or other words to talk about a matter, let's say a person. The patient thus uses a specific vocabulary which draws from the emotional way of functioning, once s/he is less worried about the rationality of his/her statements. The adaptation of the free association technique to the many-voices language of a local culture is the analysis of the composite textual corpora produced within a social context (an organization, an institution, a community, etc.) based on the detection of statistically associated words, statistical co-occurrences of words, within text units (in our case, sentences separated by full stops). Emotional Text Analysis (ETA, Carli \& Paniccia, 2003) is 
the method of interpretation of combinations of co-occurrences of words based on Matte Blanco's bi-logic theory of mind.

In one study (Caputo, Giacchetta, \& Langher, 2016) we analysed the change of the local culture of two main newspapers in Italy on the topic of AIDS, comparing the articles published during the eighties (i.e. at the beginning of attention given by the media to this issue) with the articles published in the first decade of the 2000s. We wanted to know how the affective symbolizations (i.e. the attribution of emotional meaning) of this local culture (i.e. the one represented by the two newspapers across time) on AIDS changed over time, considering the circular relationship between media and public opinion: media both express and affect the common people thoughts. After the emotional text analysis, we concluded that in the 1980s the media communication was imbued with blaming and fear of marginalized groups (gays and drug addicts); after twenty years, the media narratives expressed more the need of the society to take care and include these severely ill patients and support their families.

In this study we processed thousands of articles, which required informatics as well as statistical support, that otherwise guarantee precision and systematization in data collection and analysis. We used the software T-Lab that can process huge amounts of text, and individuate the vocabulary of the text, its specificity, and, most importantly for our purposes, the co-occurrences of words throughout the text. The co-occurrences of words in the text corpus are statistically situated in specific clusters (resulting from the analysis of lexical correspondences in the text units), which represent the nuclei of the local culture under analysis.

We use ETA also to process texts deriving from interviews with key figures, when we have the purpose to analyse the local culture of an organization or a community. The language of the key figures (Gianturco, 2004), generally persons holding important positions in a community (for example, the chief of the municipality, the school manager, some important businessmen, the responsible of citizens' committees), when requested to talk about the community to whom they belong, can be considered as a sort of "representative sample" of the local culture as they concur to build and share the common vision and representation of the community. One crucial point is that we do not analyse the interviews one by one, but we collect them in a general text corpus which is analysed as a cultural unit. The clusters deriving from the statistical analysis are thus formed by co-occurrences of words beyond the specific individuals that produce a specific interview. This is to say that the co-occurrences of words cannot be considered as the result of individual contribution of the interviewees. Indeed, 
the text corpus under analysis is composed by the sum of all individual texts, and the data processing is applied on all text units, independently of the specific interview that they come from.

\section{A dynamic clinical psychologist in the field}

I would like to offer a brief presentation of two case studies showing the analysis of unconscious processes in social phenomena in a psychoanalytical framework.

In the first case study (Langher et al., 2017a; 2017b; 2018), my collaborators and I were asked to inquire the local culture in a community after a violent earthquake in the centre of Italy, that happened less than three years ago. The local administrators were worried about the mental condition of the population since they had suffered injuries, loss of personal goods including houses and workplaces, and especially death of relatives and friends. In particular, they asked us to help the persons in charge of the social services to remodel the services offered to the population.

We proceeded with selection of key figures in the community, with the help of our commissioners. We arranged an interview with each one of them, focused on their subjective perception of their territory, currently and in the future; on its resources; on its specific features; on the expected relationship between population and social services. It can be noted that we did not ask them directly to talk about the impact of the earthquake on the community: we did not want to hurt the sensitivity of our interviewees by asking them to speak directly of that tragic event, expecting that every one of them could be personally traumatized, and that in any case the social trauma due to the earthquake would affect every individual to some extent. We did not want to approach this topic when our interviewee would not be ready to talk. Secondly, we expected that no one would really avoid mentioning the earthquake impact on their lives during the interview: we were sure that sooner or later everyone would talk about it when ready or in need to do so.

We analysed the collected texts, merged them together in one text corpus, with ETA methodology, and interpreted the local culture resulting from the clusters formed by co-occurrences of words.

The results are shown in the following table. 


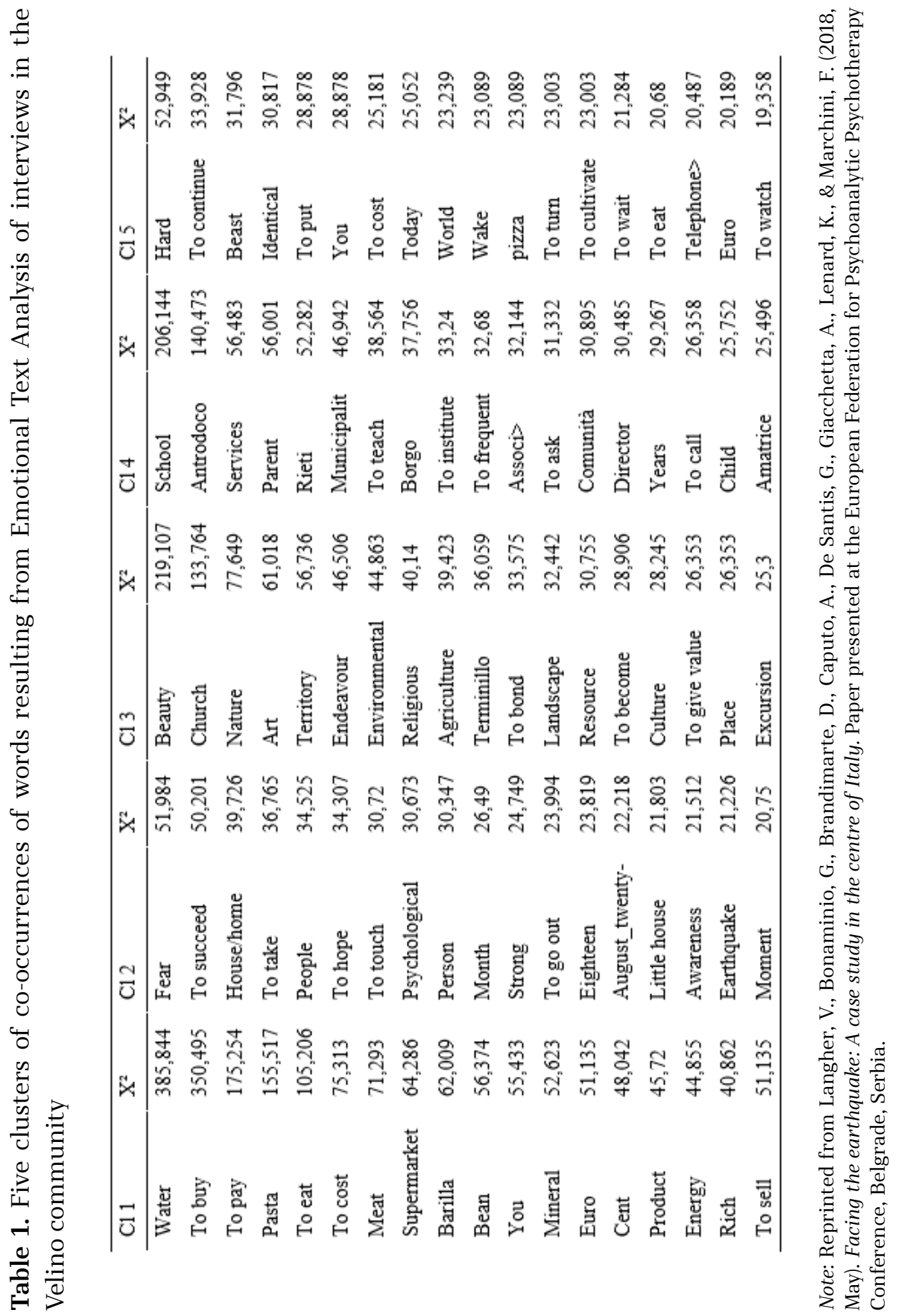


The Cl.1 seems to highlight a feeling of deprivation and need: the presence of the lemma "water», as a primary resource and necessary for survival, together with verbs related to trade (to buy, to pay, to cost) focus on the primary needs, felt as precarious and never satisfied, with the continuous referral to the need of acquiring those necessary goods.

Life condition, as it is emotionally perceived, seems to be characterized by lacking and being needy of primary resources (water, pasta, meat), which is reminiscent of the feeling of avidity. The perception of having scarce resources could stimulate a drive to collect as much as possible goods for oneself, encouraging a potentially individualistic attitude towards others. This could also suggest weak trust in one's own productive capacity (see the term «bean» in this combination: it refers to a specific bean, a typical product that is not sufficiently valued and appreciated): if one trusts his/her own capacity to provide him/ herself with what $\mathrm{s} /$ he needs and to be able to make the right effort, $\mathrm{s} /$ he will be confident to be successful in it and would not go around collecting items with greedy feelings. The Cl. 1 may thus represent a risk factor as an individualistic greedy reaction could contrast the ability of the community to count on its fundamental resource to be a social network, which, by definition, is stronger than the sum of the individuals that are part of it.

In Cl. 2 some lemmas explicitly refer to the earthquake, recalling back its terrible image (fear, house/home, eighteen, August 25, earthquake). It was an event that brutally shocked the territory (to take, impact, strong, devastation). However, a tendency for elaboration is also present (to touch, awareness), to begin with one's own emotional condition and intimate inner world (psychological, person). The earthquake is emotionally perceived as a challenge, which people in the community try to face in order to reorganize (to succeed, to restart, to take back).

It is possible that an initial elaboration of the trauma is going through this community, where at the same time people feel fear and hope for the future.

The Cl. 3 is composed of lemmas that refer to the beauty and the naturalistic resources present in the territory (nature, mountain, territory, agriculture, Terminillo). The lack of verbs in the first ten words underline a lack of action, thus evoking contemplation and idealization of the beauty of the place. Not only is the territory objectively beautiful, but people's strong emotional investment makes it particularly beautiful for them. In this Cluster the resources are represented and emotionally perceived as stable and accessible: the territory seems to deserve value (resource, to give value), particularly because of the beautiful nature and the richness of the art (mountain, nature, environment, Terminillo, church, art, 
endeavour). All this seems to be the central point to begin with to recreate a community (to bond, church, to become) and share values (to give value).

From Cl.4 development and a tendency for learning seem to emerge. The first word is "school», which evokes a relationship somehow pedagogical between the pupil and the teacher (to teach), whose outcome is child development. In this case, the desire seems to come from Velino's small municipalities towards the big city of Rieti, represented as a parent that takes care of them. One hypothesis is that, within the community, the services play the role of protectors (to guarantee, to hold), and the citizen is represented as a child. Furthermore, the services seem to be represented as the adult, expert and with more assets, able to take care of everything. The verbs «to associate» and «to cooperate», with the places "Antrodoco» and "Borgo Velino», evoke a need for socialization as a strategy for territory development. Such a need seems to represent the initial phase (to institute) of a project involving all the villages, with agreement with the other institutions (Rieti, region, Europe).

In $\mathrm{Cl} .5$ we can find lemma that refer to a community committed to hard resistance, trying to make the territory stable and familiar (hard and identical), through the continuity of its tradition and identity; a territory that, otherwise, moves by itself (beast) and changes when time goes by (world, today). In this Cluster the verb "to cost» is present, meaning that the people feel an intense, although lonely, commitment. The emotional perception here is that this community is different, lonely, still proud, which makes these people divided from the people coming from other places: these people have to take their world on their own shoulders.

After the analysis of the results, we suggested to our commissioners to focus on the need for dependence on the institutions, and to consider the social services as an institutional place to take care of this need, but to support the population to grow emotionally, not only to protect them. We particularly focused on the risk to make them passive, considering the tragedy that they had to face which could have solicited in the service providers the emotional representation of a needy child. In this local culture, the need for support and protection was joined with the need to be helped to grow up, and the image of the child that goes to school was for us the more appropriate to describe this emotional dynamic, as this community needed to count on its own strength and wanted to move on.

In the second case study, hereby briefly presented, we chose the same approach in order to understand the affective symbolization of the refugees in a small town in Germany, in cooperation with a German colleague who was 
interested in enhancing the quality of inclusive processes in that small portion of German society.

We proceeded with our interviews with the selected key figures and performed ETA on the text corpus in order to understand the local culture under analysis. The results are shown in the following table.

Table 2. Four clusters of co-occurrences of words resulting from Emotional Text Analysis of interviews in the Viernheim community

\begin{tabular}{l|c|l|c|l|l|l|l}
\hline \multicolumn{2}{c|}{ Cluster 1 } & \multicolumn{2}{c|}{ Cluster 2 } & \multicolumn{2}{c}{ Cluster 3 } & \multicolumn{2}{c}{ Cluster 4 } \\
\hline Lemma & $\chi^{2}$ & Lemma & $\chi^{2}$ & Lemma & $\chi^{2}$ & Lemma & $\chi^{2}$ \\
\hline Mensch & 375,31 & Helfen & 155,82 & Integration & 142,65 & Arbeit & 110,15 \\
Problem & 121,20 & Wohnen & 116,74 & Erwartung & 68,75 & Kommen & 101,14 \\
Sehen & 81,47 & Seite & 103,20 & Viernheim & 62,23 & Deutsch & 94,42 \\
Medien & 63,43 & Geflüchtete & 102,15 & Glaube & 39,74 & Gut & 62,07 \\
Ausländer & 54,48 & Kind & 85,29 & Wichtig & 36,12 & Frauen & 51,38 \\
Bekommen & 42,05 & Haus & 81,61 & Schwer & 28,52 & Offen & 37,73 \\
Gekommen & 31,65 & Gezeigt & 41,07 & Kultur & 21,41 & Familie & 35,64 \\
Alt & 20,19 & Nehmen & 33,49 & Vollständig & 21,41 & Türkei & 29,90 \\
Tausend & 19,84 & Situation & 27,88 & Antwort & 19,55 & Land & 27,15 \\
Unterschied & 18,23 & Gewohnheit & 20,09 & Sprache & 18,56 & Mann & 26,23 \\
\hline
\end{tabular}

Note: Cluster 1: human being, problem, seeing, media, foreigners, receiving, thousands, arrived, old, difference, politics, dangerous

Cluster 2: help, living, side, child, refugee, house, showing, habits, situation

Cluster 3: integration, expectation, faith, important, heavy, entirely, language, answer

Cluster 4: work, coming, German, good, woman, open, family, Turkey, country, man, to get, money.

Unpublished data, quotation from: Groterath, A. (Ed.) (2018). Die Viernheim-Studie: Eine psychologische untersuchung zur integration von geflüchteten in einer deutschen gemeinde [The Viernheim study: A psychological study on the integration of refugees in a German community]. Retrieved from https:// www.socialnet.de/materialien/28146.php

We suggested the interpretation of a complex emotional dynamic affecting the relationship between the refugees and the host community, based on the host community controversial feelings: fear of the unknown, potentially dangerous counterpart (Cl. 1), guilt for the fragile and "needy as a child" condition of the refugees $(\mathrm{Cl} .2)$, pressure from the whole country for the success of the 
integration of refugees (Cl. 3), and finally pride for the German values with the particular position of the word "Turkey" as a clue indicating the successful inclusion (maybe assimilation?) of what was stranger once, but it is German now (Cl. 4).

It can be seen in these two examples that dynamic clinical psychology can offer a knowledge both on subtle processing running through the social contexts, and "across the board" that can be fruitfully integrated in different fields. It can help other professional profiles, such as social workers, policy makers, but also architects and engineers, in managing complex situations involving entire communities, opening the possibility to deeply penetrate the emotional mechanisms undergoing the interpersonal plot regulating the coexistence among individuals in a given context. It can also help in designing and realizing practical solutions to improve the communities' quality of life.

\section{Challenges for today: social media conformism and the lack of critical thinking}

In conclusion I want to explain why I chose the title "A dangerous method".

This is the title of a quite recent movie which represented the very beginning of psychoanalysis through the passionate story of the relationship between Sigmund Freud and Carl Gustav Jung, the recognized founder of psychoanalysis and one of its first pioneers.

The story of psychoanalysis was crossed by charismatic personalities, struggling to state the truth of the deep nature of the human mind which was primarily imbued by drives, passions, desires, untellable words, uncommunicable thoughts, censures, defences, irrationality, instincts, darkness, a live chaos that the poor human being was given the task do domesticate.

The psychoanalytical method was "dangerous" indeed, contrasting the image of a calm, plain, rational, thoughtful, mature, civilized human being, devoted to the respect of unbreakable values, rationality or clean consciousness, dedicated to family, work and possibly religion. Its effect was explosive, as explosive were the discussions among the psychoanalysts, with uncountable wars, fights, separations and splittings.

The spirit of the psychoanalytic treatment can be resumed by Freud's wellknown quotation "where Id was, there Ego shall be", meaning that only facing our passionate and obscure side we can exert real control based on understanding 
and balance, not on repression and denegation. But it is the ability to think, to reflect, to observe, to recognize, to test the reality that wins in the end.

While observing how public opinion flows nowadays, I happen to be surprised noticing how it is increasingly formed by simple thoughts, stereotypes, and primary emotions (e.g. conspiracy, flat earth or no-vax societies, racism), instead of rational analytical thinking, as if we have lost, at some level, our capacity to think. Perhaps the quality of education has decreased in the last decades. Maybe financial crises and societal disruptions did prevent the educational systems in reaching their noble aim to nourish and open the minds of our young generations. If a country does not invest enough human and financial resources in education, the negative effect on the young generations can be clearly observed. Is this negative effect seen as a damage by everyone or maybe not? Is it arguable that the more the mind is simple the easier it is to be manipulated, to be influenced? The more an individual is prone to his/her primitive emotions without being aware of them, the more $\mathrm{s} /$ he is delusional that $\mathrm{s} / \mathrm{he}$ is choosing, autonomously deciding, while in facts s/he is being guided and oriented. Gaining the consensus from people is a huge business: on one side, one can sell products and services - and we got used to it over time, giving up a share of our "free will" and accepting to buy products and services that sometimes we do not really need; on the other side public opinion can be moved from one side to another. This is much more disquieting to me because this affects people's political choices and attitudes which otherwise require reality testing, fact checking and cognitive elaboration. As far as I can understand now, people are guided more by primary or primitive emotions than rational thinking, instead.

Once again, a dynamic clinical approach in analysing human behaviour at the societal level can highlight these emotional collective processes and enhance the capacity to think over them, to elaborate these primary or primitive emotions and restore the rational, understanding and knowledge-based thinking. I must admit that I am not optimistic, as I see this method potentially "dangerous" today, as it increases our freedom degrees in choices by which we seem to be scared but it seems to be very fruitful when the question is how to gain consensus.

However, I call to cause university teachers: we have a responsibility in supporting open mindedness in young generations and their ability to explore different contexts. I am convinced that we must invest energy and time in the entire network among universities in different countries, and to promote the many programs supporting students' mobility. We have to send this message to our students: first explore, then know! The "dangerous method" (but... dangerous for whom? Maybe for the businesspersons of social consensus) is that of promoting 
analytical reasoning, awareness, complexity of thinking, and autonomy in judgment, recognizing when it is an emotional primary internal drive that takes control of their behaviour and choices, and when it is their ability to test the reality that supports them in understanding what they know and in taking what they want. 


\section{References}

Caputo, A., Giacchetta, A., \& Langher, V. (2016). AIDS as social construction: Text mining of AIDS-related information in the Italian press. AIDS Care, 28(9), 1171-1176.

Carli, R., \& Paniccia, R.M. (2003). Analisi della domanda. Teoria e intervento in psicologia clinica [Analysis of demand. Theory and intervention in clinical psychology]. Bologna: Il Mulino.

Fornari, F. (1975). Genitalità e cultura [Genitality and culture]. Milano: Feltrinelli.

Fornari, F. (1976). Simbolo e codice [Symbol and code]. Milano: Feltrinelli.

Gianturco, G. (2004). L'intervista qualitativa. Dal discorso al testo scritto [Qualitative interview. From discourse to written text]. Milano: Guerini e Associati.

Grasso, M., \& Salvatore, S. (1997). Pensiero e decisionalità. Contributo alla critica della prospettiva individualista in psicologia [Thought and decision making: A contribution to the critic of the individualistic perspective in psychology]. Milano: Franco Angeli.

Groterath, A. (Ed.) (2018). Die Viernheim-Studie: Eine psychologische Untersuchung zur Integration von Geflüchteten in einer deutschen Gemeinde [The Viernheim study: A psychological study on the integration of refugees in a German community]. Retrieved from https://www.socialnet.de/materialien/28146.php

Langher, V., Bonaminio, G., Brandimarte, D., Caputo, A., De Santis, G., Giacchetta, A., Lenard, K., \& Marchini, F. (2018, May). Facing the Earthquake: A case study in the centre of Italy. Paper presented at the European Federation for Psychoanalytic Psychotherapy Conference, Belgrade, Serbia

Langher, V., Bonaminio, G., Brandimarte, D., Caputo, A., De Santis, G., Giacchetta, A., Marchini, F., \& Nannini, V. (2017, November). Terremoto e resilienza delle comunità: una ricerca esplorativa nel territorio dell'Alta Valle del Velino [Earthquake and resilience: An exploratory research on the territory of the Alta Valle del Velino]. Paper presented at La Psicologia come Scienza della Salute: Pre-atti del XII Congresso Nazionale Associazione S.I.P.S.A. Società Italiana di Psicologia della Salute. Firenze, Italy.

Langher, V., Caputo, A., Nannini, V., Fregonese, C., Bonaminio, G., Brandimarte, D., De Santis, G., Giacchetta, A., \& Marchini, F. (2017). Velino. Un progetto di ricerca dell'ordine degli psicologi del Lazio [Velino. A research project by the Lazio regional council of psychologists]. Scientific report.

Matte Blanco, I. (1975). The Unconscious as Infinite Sets. An Essay in Bi-Logic. London: Gerald Duckworth \& Company Ltd. 
Salvatore, S., Freda, M. F., Ligorio, B., Iannaccone, A., Rubino, F., Scotto di Carlo, M., Bastianoni P., \& Gentile, M. (2003). Socioconstructivism and Theory of the Unconsious: A gaze over a research horizon. European Journal of School Psychology, 1(1), 9-36. 


\title{
ОПАСЕН МЕТОД: ДИНАМИЧКАТА КЛИНИЧКА ПСИХОЛОГИЈА И ПРЕДИЗВИКОТ ДА СЕ РАЗБЕРЕ ЕМОЦИОНАЛНОСТА ВО СОЦИЈАЛЕН КОНТЕКСТ
}

\author{
Вивиана Лангер
}

\section{Кратка содржина}

Во текстот се дискутира на кој начин и во која мера емоционалноста влијае на гледиштата, верувањата, ставовите, односно на социјалното однесување на цели заедници. Конструктот на несвесното е презентиран од современа перспектива, која ги надминува личносните конфликти, неразрешените искуства и психопатологијата. Согласно теоријата на Мате Бланко (1975) за двојната логика на умот, емоциите - како процеси на атрибуција на значење на објекти, луѓе и настани, засновани на примарни категории (добро и лошо, големо и мало, внатре и надвор) - може да се споделуваат меѓу групи индивидуи, како и меѓу цели заедници во форма на „локални култури“ (Carli \& Paniccia, 2003), кои го регулираат нивното социјално однесување кон одредени социјални стимули. Динамичката клиничка психологија обезбедува теоретска рамка, инструменти и методологија, како што е емоционалната анализа на текст, заснована на лексичка анализа на јазикот, што може да го открие опсегот на споделена емоционалност во социјален контекст, која на тој начин ќе стане експлицитна, и ќе може да се елаборира и трансформира во непристрасно и свесно, рационално мислење. Накратко се презентирани две студии на случај кои покажуваат како динамичката клиничка психологија обезбедува сеопфатно знаење, кое може делотворно да се интегрира во разни области, и да им помогне на други профили стручњаци при осмислување и реализирање практични решенија за подобрување на квалитетот на животот во заедниците, како и зголемување на нивниот капацитет за справување со сложен сет на информации, на тој начин превенирајќи ги мноштвото стереотипи, симплифицираното мислење и примарните емоции. Во заклучокот ги повикувам универзитетските професори на нивната одговорност да ја поддржат отвореноста на умот кај младите генерации и нивната способност да истражуваат различни контексти.

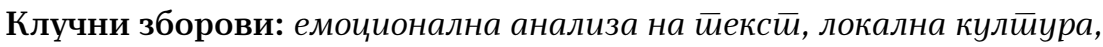
сӣуyguја на случај 